\title{
Socio-Demographic Determinants of Malnutrition among Children of 1-6 Years of Age in Rural Meerut
}

\author{
${ }^{1}$ A.K. Singh, ${ }^{2}$ Seema jain, ${ }^{3}$ M. Bhatnagar, ${ }^{4}$ J.V. Singh, ${ }^{5}$ S.K. Garg, ${ }^{6}$ H. Chopra , \\ ${ }^{7}$ S.K. Bajpai. \\ Department of Community Medicine, LLRM Medical College, Meerut.
}

\begin{abstract}
Background:Knowledge of various causes and coexisting factors is necessary to combat malnutrition in community. Objectives: To study the prevalence of PEM and its various socio-demographic correlates in children of 1-6 years in rural community. Method: A cross-sectional study by house to house visit covering 406 children (1-6 years) from the sub centre villages of additional PHC Amarpur in Machhra block of Meerut district. Result: The prevalence of underweight was $57.4 \%$ according to IAP classification with the proportion of grade I, II and III under nutrition being $68.2 \%, 29.2 \%$ and $2.6 \%$ and none of the children in grade IV under nutrition. The prevalence of underweight was significantly higher in 3-6 years children (64.1\%) as compared to 1-3 years children (47.6\%) and there was no significant difference in the sex and caste. Prevalence of underweight was significantly higher in children belonging to nuclear families. There was direct association of underweight in relation to poor housing and environmental sanitations and low standard of living index. The prevalence of underweight was low in children of literate mother. Conclusion: The study suggests to focus on preschool children for growth monitoring, especially in low socioeconomic families, approaching them by the help of anganwadis, and educating mothers of preschoolers about the impact of environmental sanitation on health..
\end{abstract}

Key Words: under nutrition, malnutrition, nutritional correlates, nutritional status, PEM

\section{Introduction:}

Good child health is imperative for economic and social development. The prevalence of proteinenergy malnutrition in South-East Asia is the highest in the world. This high prevalence and the large population of the region imply that more than half of all malnourished children in the world are found in this region.

Despite improvements in some measures, poor nutrition is still a serious problem, especially in U.P. among children from disadvantaged socioeconomic groups. It is therefore, necessary to make an ecological diagnosis of the various causation or co-existing factors responsible for malnutrition in a community. The present study was undertaken to find out the PEM prevalence among 1-6 years age group and identifying the different variables which affect the prevalence of PEM among rural population of Meerut district.

\section{Materials and methods:}

The present study was conducted among children (1-6 year) in all the six sub center villages of randomly selected additional primary health center Amarpur of Block level Primary health center Machhra, the Rural Field Practice area of the Department of Community Medicine, L.L.R.M. Medical College Meerut. A multi-stage random sampling technique was used for selection of villages. An optimum sample size for study was obtained by an estimated protein energy malnutrition prevalence of 50\% in children 1-6 years old with $10 \%$ relative precision and $95 \%$ confidence interval, the minimum sample size calculated out was 384 children. A total of 406 children (1-6 years) were covered by house to house visit. A detailed information was collected on a predesigned and pretested proforma by oral questionnaire and supplemented by physical and anthropometric examination of child. PEM was calculated by IAP classification. The data compilation and analysis was done by using SPSS and epi Info.

\section{Results:}

The overall prevalence of underweight was $57.4 \%$ and proportion of grade I, II and III under nutrition was $68.2 \%, 29.2 \%$ and $2.6 \%$ respectively with no child in grade IV under nutrition[Table-I].As shown in TableII, the prevalence of under weight in children 3-6 years $(64.1 \%)$ was significantly higher than in 1-3 years children $(47.6 \%)$ with no significant difference in prevalence of under nutrition among male $(56.9 \%)$ and female $(58.1 \%)$ children. 
The majority (59.1\%) children belonged to joint family and the rest $40.9 \%$ to nuclear family. Prevalence of underweight was $63.8 \%$ and $52.9 \%$ among children (1-6 years) belonging to nuclear and joint families respectively $(\mathrm{p}<0.05)$ as shown in table-III.

Prevalence of underweight did not show any statistically significant difference in different caste groups $[\mathrm{P}>0.1]$ but the prevalence of underweight was significantly decreased $[\mathrm{P}<0.001]$ with rise in $\mathrm{SLI}^{1}$ i.e. maximum (86.7\%) in low SLI [Table-III].

The difference in prevalence of underweight in relation to housing and environmental sanitation ${ }^{2}$ was found to be statistically significant $[\mathrm{P}<0.001]$ as maximum children were underweight $(81.4 \%)$ who were living in poor housing and environmental sanitation conditions. The prevalence of underweight was found significantly higher $[\mathrm{P}<0.05]$ in children of illiterate mother $(63.0 \%)$ as compared to children of literate mothers $(50.0 \%)$ as shown in table-III.

\section{Discussion:}

Prevalence of malnutrition and its relation to various epidemiological correlates in 406 children was assessed on the basis of weight for age. Out of these $40.4 \%$ of children were in 1-3 years age group while $59.6 \%$ were in 3-6 years age group. $57.1 \%$ were males and $42.9 \%$ were females.

The overall prevalence of underweight as assessed by IAP classification was $57.4 \%$ The difference in prevalence of underweight in relation to age was found to be statistically significant $(\mathrm{p}<0.001)$. Sharma $(2003)^{3}$ in urban Meerut reported overall prevalence of underweight in 1-6 years age group as 51.5\% and reported same significant difference in prevalence of underweight in relation to age. Overall more preponderance of malnutrition among rural children as compared to urban children may be attributed to the better parental care given to the urban children. A comparatively higher prevalence of underweight was reported by by Vijayaraghavan and Rao $(1998)^{4}$ i.e $60.0 \%$. On the contrary to present study Swami et al $(2001)^{5}$ observed that malnutrition was more prevalent in the younger age group, i.e. $\leq 3$ years and started declining after third year. In NFHS III (2005-06) $)^{1}$ done in children $<5$ years of age prevalence of underweight was $42.5 \%$.

The prevalence of PEM being significantly higher $(\mathrm{p}<0.05)$ in the nuclear family $(63.8 \%)$ in comparison to joint family (52.9\%), may be due to the reason that children in the joint family are nutritionally better cared as there is tendency to share the food with the children by all the family members.

No statistically significant difference was found in the prevalence of malnutrition in relation to the sex

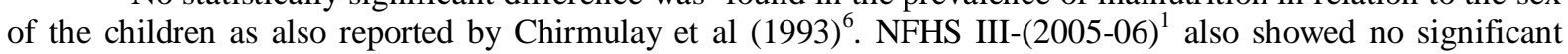
difference in prevalence of underweight among boys and girls.

In the present study, according to IAP classification the proportion of children with grade I, II and III PEM were $68.2 \%, 29.2 \%$ and $2.6 \%$ respectively and none of the children was in grade IV. Mild, moderate and severe grades of malnutrition reported by various other workers are as follows: Srivastav et al $(1979)^{7} 29.5 \%$, $10.6 \%$ and 2.9\%; Kakkar et al $(1987)^{8} 38 \%, 31 \%$ and $9 \%$. In NFHS III $(2005-06)^{1}$ values for, moderate (-2SD) and severe grades of malnutrition (-3SD) according to underweight were $42.5 \%$ and $15.8 \%$ respectively with corresponding figures for U.P. being $42.4 \%$ and $16.4 \%$ respectively.

In the present study PEM was inversely associated with standard of living index with prevalence of underweight being $86.7 \%$ in children of low standard of living index $(\mathrm{p}<0.001)$ as also observed in NFHS III $(2005-06)^{1}$ both at national level and Uttar Pradesh level. A similar finding of malnutrition being more prevalent in children belonging to lower socioeconomic groups was also found by, Rao et al (1990) ${ }^{9}$, Jayaseelan et al $(1997)^{10}$ and Sharma $(2003)^{3}$. The reason for malnutrition being more prevalent among lower socioeconomic groups may be due to their lower purchasable capacity for food and unavailability of hygienic and healthy living environment among them.

The prevalence of underweight in the present study was higher in children of illiterate mother's $(63.0 \%)$ as compared to children of literate mother's (50.0\%). Similar results that prevalence of malnutrition decreased with increasing parental literacy was found by Arya et al (1991) ${ }^{11}$, Saito et al (1997) $)^{12}$, NFHS III (2005-06) Sharma $(2003)^{3}$ and Bishnoi et al $(2004)^{13}$. In the present study it was found that maximum children were underweight $(81.4 \%)$ when housing and environmental sanitation conditions were poor while minimum were underweight $(24.0 \%)$ when environmental and sanitary conditions were good $(\mathrm{p}<0.001)$ which is comparable with finding of Sharma $(2003)^{3}$ and Bishnoi et al $(2004)^{13}$.

\section{Conclusion:}

The present study shows that the prevalence of underweight was significantly higher in children of 3-6 years of age, nuclear family, low standard of living index, mother's illiteracy and poor housing and environmental sanitation with no significant relation with sex and caste. The study suggests intensification of ICDS with multi sectorial strengthing., that can be achieved by help of ASHA, AWW,ANM and local village self help groups. RCH II has also incorporated IMNCI strategies, which mainly focus on screening the protein energy mal nutrition in its budding phase. Such programmes should be evaluated timely, to curb this issue. 
Table-I

Age and Sex wise Prevalence of PEM in Children (1-6 Years)

\begin{tabular}{|ccccccc|}
\hline Age(Years) & $\begin{array}{c}\text { No. of } \\
\text { children }\end{array}$ & $\begin{array}{c}\text { Male } \\
\text { Underweight }\end{array}$ & $\begin{array}{c}\text { No. of } \\
\text { children }\end{array}$ & $\begin{array}{c}\text { Female } \\
\text { Underweight }\end{array}$ & $\begin{array}{c}\text { No. of } \\
\text { children }\end{array}$ & $\begin{array}{c}\text { Total } \\
\text { Underweight }\end{array}$ \\
& 100 & 44 & 64 & 34 & 164 & 78 \\
& $(61.0)$ & $(44.0)$ & $(39.0)$ & $(53.1)$ & $(40.4)$ & $(47.6)$ \\
$3-6$ & 132 & 88 & 110 & 67 & 242 & 155 \\
& $(54.5)$ & $(66.7)$ & $(45.5)$ & $(61.0)$ & $(59.6)$ & $(64.1)$ \\
Total & 232 & 132 & 174 & 101 & 406 & 233 \\
& $(57.1)$ & $(56.9)$ & $(42.9)$ & $(58.1)$ & $(100.0)$ & $(57.4)$ \\
\hline
\end{tabular}

*Figures in parenthesis show percentages

Age $\chi^{2}=10.87, \mathrm{df}=1, \mathrm{p}<0.001$

Sex $\chi^{2}=0.05, \quad \mathrm{df}=1, \mathrm{p}>0.5$

Table-II

PEM in Children (1-6 Years) According to Its Severity [According I.A.P. Classification]

\begin{tabular}{|c|c|}
\hline Severity & Underweight \\
\hline Grade I & $159(68.2)$ \\
\hline Grade II & $68(29.2)$ \\
\hline Grade III & $6(2.6)$ \\
\hline Grade IV & - \\
\hline Total & $233(100.0)$ \\
\hline
\end{tabular}

*Figures in parenthesis show percentages

Table-III

Physico-social correlates of PEM in children (1-6 years)

\begin{tabular}{|c|c|c|c|}
\hline Variables & No. of Children & Underweight & Significance \\
\hline $\begin{array}{l}\text { Type of family } \\
\text { Nuclear } \\
\text { Joint }\end{array}$ & $\begin{array}{l}166(40.9) \\
240(59.1)\end{array}$ & $\begin{array}{l}106(63.8) \\
127(52.9)\end{array}$ & $\begin{array}{l}\chi^{2}=4.80 \\
\text { df }=1, p<0.05\end{array}$ \\
\hline $\begin{array}{l}\text { Caste } \\
\text { Savarn Hindu } \\
\text { Other backward class } \\
\text { Schedule caste }\end{array}$ & $\begin{array}{c}70(17.2) \\
262(64.6) \\
74(18.2)\end{array}$ & $\begin{array}{c}36(51.4) \\
149(56.9) \\
48(64.9)\end{array}$ & $\begin{array}{l}\chi^{2}=2.74 \\
\text { df }=2, \quad p>0.1\end{array}$ \\
\hline $\begin{array}{l}\text { SLI } \\
\text { High } \\
\text { Medium } \\
\text { Low }\end{array}$ & $\begin{array}{l}138(34.0) \\
148(36.4) \\
120(29.6)\end{array}$ & $\begin{array}{l}36(26.1) \\
93(62.8) \\
104(86.7)\end{array}$ & $\begin{array}{l}\chi^{2}=99.15 \\
\mathrm{df}=2, \quad \mathrm{p}<0.001\end{array}$ \\
\hline $\begin{array}{l}\text { Housing and } \\
\text { environmental condition } \\
\text { Poor } \\
\text { Satisfactory } \\
\text { Good }\end{array}$ & $\begin{array}{c}97(23.9) \\
259(63.8) \\
50(12.3)\end{array}$ & $\begin{array}{c}79(81.4) \\
142(54.8) \\
12(24.0)\end{array}$ & $\begin{array}{l}\chi^{2}=46.44 \\
\mathrm{df}=2, \quad \mathrm{p}<0.001\end{array}$ \\
\hline $\begin{array}{l}\text { Mother's Education } \\
\text { Illiterate } \\
\text { Literate } \\
\text { TOTAL }\end{array}$ & $\begin{array}{l}230(56.6) \\
176(43.4)\end{array}$ & $\begin{array}{l}145(63.0) \\
88(50.0)\end{array}$ & $\begin{array}{l}\chi^{2}=6.94 \\
\mathrm{df}=2, \quad \mathrm{p}<0.05\end{array}$ \\
\hline
\end{tabular}

*Figures in parenthesis show percentages 


\section{References:}

[1] National Family Health Survey-III (2005-06). International Institute of Population Sciences,Deonar, Mumbai, India, September 2007.

[2] Garg et al (1983) Morbidity profile with reference to housing and environmental status criteria. Indian J. Pub. Health XVIII (3):85

[3] Sharma B., Bhatnagar M, Singh JV, Garg SK, Chopara H; An epidemiological study of protein energy Malnutrition(PEM) in children of 1-6 years of age in urban area of Meerut. (2003)

[4] Vijayaraghavan K, Rao DH;Diet and nutrition situation in rurar India;Indian J Med Res.1998 Nov;108:243-53

[5] Swami et al. Nutritional status of pre-school children in an integrated child development service (ICDS block of Chandigarh). J Indian Med Assoc 2001; 99(10): 554-6.

[6] Chirmulay et al. Nutritional status of tribal under-five children in Ahmadnagar district, Maharashtra in relation to weaning/feeding practices. Indian Pediatr 1993; 30(2): 215-22.

[7] Shrivastava VK, Srivastava BC, Nandan D, Vidya Bhushan. Protein energy malnutrition among pre-school children in a rural population of Lucknow. Indian Pediatr 1979; 16: 507.

[8] Kakker S et al. Nutritional status of preschool children in rural Hisar. Indian J Nutr Dietet 1987; 24: $204-208$.

[9] Rao et al. Discriminant function analysis: a case study of some socio-economic constraints on child nutrition. Indian J Med Res 1990; 92: 66-71.

[10] Jeyaseelan et al. Risk factors for malnutrition in south Indian children. J Biosoc Sci 1997; 29(1): 93-100.

[11] Arya A, Devi R;Influence of maternal literacy on the nutritional status of preschool children;Indian J pediatr.1991 MarApr;58(2):265-8

[12] Saito et al. A case control study of maternal knowledge of malnutrition and health care seeking attitudes in rural south India. Yale J Biol Med 1997; 70(2): 149-60.

[13] Bishnoi P, Sehal S, Kwatra A; Anthropometric measurements of preschool children as effected by socio-economic factors; Asia Pac Clin Nutr.2004,13(Suppl):S132. 